\title{
School Administrators, ICT Coordinators and Teachers' Metaphorical Conceptualizations of Technology
}

\author{
Şirin Karadeniz \\ Bahçeşehir University, Faculty of EducationalSciences, Department of Computer Education and Instructional Technologies, Istanbul, \\ Turkey
}

\begin{abstract}
The purpose of this study is to investigate the perceptions of school administrators, ICT coordinators and teachers regarding the concept of "technology". 87 participants completed the prompt “Technology is like...because...” by focusing on one metaphor about technology. Qualitative and quantitative techniques were used to figure out the metaphor categories and whether they differentiate according to participants' position, gender and age variables. Content analysis was used to analyze the perceptions of the participants. Findings of the study showed that the participants indicated 60 valid metaphors which were grouped into five categories: 1) Technology as a changing and developing entity (e.g. children, fashion); 2) Technology as a facilitator (e.g. key, organ); 3) Technology as a needed entity (e.g. food, air); 4) Technology as a useful and harmful entity (e.g. viruses, sugar); 5) Technology as a diffusional entity (e.g. octopus, ocean). It was found that the majority of metaphorical conceptualization categories aligned with "a useful and harmful entity" by administrators, "a facilitator" by ICT coordinators and "a changing and developing entity" by teachers. According to the findings of the quantitative analyses there is no significant relationship between the participants’ perceptions of technology regarding age and gender. However significant relationship was found between the participants' perceptions of technology and their position.
\end{abstract}

Keywords Technology, Metaphor, Administrators, ICT Coordinators, Teachers

\section{Introduction}

There has been great increase in using information and communication technologies (ICT) in schools. The use of technology can be effective when these factors are presented in schools; available ICT resources which can be used in every area of the school, technical support for teachers, teacher training of ICT skills and effective ICT leadership (Somekh et al 2002). Teachers' knowledge and skills about ICT, confidence level, attitudes towards technology, pedagogical beliefs regarding the value of the use of technology have been suggested as effective barriers which hinder technology use in classroom (Lai, Pratt \&Trewern, 2001). In fact, Lam (2000) asserted that the main reasons for the teachers' decisions regarding technology depend on whether the teacher was personally convinced of the benefits of using technology for instruction. Hew \& Brush (2007) identified the general barriers typically faced by K-12 schools when integrating technology into the curriculum; resources, institution, subject culture, attitudes and beliefs, knowledge and skills, and assessment. They further describe the strategies to overcome such barriers; having a shared

* Corresponding author:

sirin.karadeniz@bahcesehir.edu.tr (Şirin Karadeni z)

Published online at http://journal.sapub.org/edu

Copyright (C) 2012 Scientific \& Academic Publishing. All Rights Reserved vision andintegration plan, overcoming the scarcity of resources, changing attitudes and beliefs, conducting professional development, and reconsidering assessments. It should be noted that these strategies are all interrelated. For example, conducting professional development could positively influence the attitudes towards technology or vice versa. Actually, the positive attitudes about technology can speed up the technology integration at schools. So the educators' attitudes toward technology should be determined in order to draw the technology integration road map. Therefore; this study examines the perceptions of school administrators, ICT coordinators and teachers regarding the concept of "technology".

The literature on technology integration also suggested that school technology plans and leadership factors are important obstacles at school level integration process (Gülbahar, 2007; Saban, 2007; Sugar \&Hollomon, 2009). This process should to be managed by educators who have technology leadership skills. Ho wever school administrators shouldn't be seen as the dominant source of innovation and change. The leadership should be shared among the key stakeholders (such as head teachers, ICT coordinator and school administrator) for the better integration of technology (Hsu \& Sharma, 2008; Kocolowski, 2010; Sugar \&Hollomon, 2009). Moreover, successful use of ICT depends upon the commitment of a team. This senior management team could be formed with ICT coordinator, 
teachers and technicians depending upon the size of the school (So mekh et al 2002).

ICT coordinators (also called formator teacher) are also have a key role in integration of technology process (Lai \&Pratt, 2004). They perform several tasks within a school and play multiple roles that in fluence efficiency of teaching and learning (Sugar \&Hollomon, 2009). According to Lucock\& Underwood (2001) one of the responsibilities of the ICT coordinators is to guide ICT teaching and learning in school. Research on ICT coordinators' roles indicated that they are responsible for professional development of teachers, students' ICT skill levels, the development of infrastructure and the use of ICT to support teaching and learning, and they demonstrated roles as a planner, a budgeter, a pedagogical-didactic supporter, a technical supporter and a technology leader (Cleere, 2009; Devolder, 2009; Lai \& Pratt, 2004; So mekh et al 2002).

Lai \& Pratt (2004) determined that the ICT coordinators were both knowledgeable and enthusiastic about ICT use. Devolder (2009) found that ICT coordinators have a positive perception towards the ICT objectives and this positive perception is influenced by the inclusion of a planning role and pedagogical and didactic support role. However ICT coordinators seem as an 'electronic janitor' who maintains the hardware (Reilly 1999). This situation creates the lack of time problem and increase the workload of the ICT coordinators who mainly provide technical support than coordinating the use of ICT to support teaching and learning process (Cleere, 2009; Somekh et al 2002).

Orhan\&Akkoyunlu (2003) investigated difficulties faced by ICT coordinators during ICT integration process. They found that most of the ICT coordinators weren't satisfied with their job because of work overload and negative attitude of school administrators toward using technology at schools. School administrators have a crucial role to create the conditions to develop ICT policies and integration strategies in a collaborative approach (Tondeur et al, 2008). The negative attitudes of school administrators towards technology can be a critical predictor of unsuccessful ICT integration, since it adversely affect the technology use of teachers and ICT coordinators. As Çakır\& Yıldırım (2009) stated, the teachers' attitudes toward technology and innovations shape their use of technology. In fact, the teachers who use technology more in schools, likely have more positive attitudes (Akkoyunlu, 1995). Albirini (2006) found that teachers have positive attitudes toward ICT in education and their attitudes could be determined by computer attributes, cultural perceptions and computer competence. In addition, Lam (2000) found that teachers see technology as a tool, as a means to enhance teaching and promote learning, not as an end in itself.

In this respect, effective technology integration requires collaborative effort of school administrators, teachers and ICT coordinators. Th is study investigates these stakeholders' perceptions regarding technology in a vivid manner by using metaphors. The next section gives brief review on the literature about metaphors in educational research.

\subsection{Metaphor Studies in Education}

Lakoff and Johnson (1980) argued that "human conceptual system is metaphorically structured and defined (p.6)". Oxford et al (1998) explain metaphor as “...employing a familiar object or event as a conceptual tool to elucidate features of a more complex subject or situation (p.4)". Metaphors began to have validity in educational research as the researchers attempt to understand the study context. The educational researchers try to accomplish for the words of teachers and administrators to draw a new meaning of pre-existing knowledge or practice (Jensen, 2006).

There are a number of studies examining the metaphors used by pre-service teachers to elucidate their perceptions about the teacher (Ocak \&Gündüz, 2006; Saban, Kocbeker\&Saban, 2007), student (Saban, 2009), gifted student (Eraslan\&Çapan, 2010), teaching (Bu llough, 1991; Bullough\& Stokes, 1994), diversity (Parsons, Brown \& Worley, 2004), language teacher (Oxford et al, 1998; Guerrero \&Villamil, 2000; Nikitina\&Furuoka, 2008), science and technology teacher (Afacan, 2011), technology (Gök\&Erdoğan, 2010) and social network (Güro $1 \&$ Donmuş, 2010).

Metaphor has also been a useful tool for understanding novice teachers' professional identity through the examination of "new teachers' metaphorical representations of themselves as a teacher" in the first-year of teaching. The findings of the study showed that development of a professional identity is complex and problematic process for new teachers (Thomas \& Beauchamp, 2011).

Metaphors were also used to reveal the perceptions of students, teachers and administrators about the concept of principal.The findings of the study revealed that teachers and admin istrators see principals as researcher, controller, mentor, educator, director, coach, conductor and leader. Moreover, there were significant differences among teachers and administrators on the perception of the principal concept. However there were no significant differences with respect to gender, educational state and symbol seniority (Cerit, 2008).

Silman\& Şimşek (2006) used metaphors to understand the perceptions of teachers and administrators who work at Turkish and American primary schools on their schools and central educational organizations. The findings showed that Turkish participants used metaphors which represented the centralized characteristics of Turkish school system, whereas American participants used metaphors regarding the participatory and collaborative work culture of their school.

Gök\&Erdoğan (2010) examined the primarypre-service teachers' perceptions oftechnology. They found the following nine categories; needed, constantly changing, developing, harmful, beneficial, addictive, both beneficial and harmful, rapidly developing and facilitating our life. Though they found significant differences in terms of preservice teachers' general point average and learning to use technology, there wasn't any significant difference in 
terms of gender, grade and the frequency of technology use and background information about technology use.

Saban (2010) asked computer pre-service teachers to provide metaphors about the concept of internet. She found that pre-service teachers, who studied their last year in Department of Computer Education and Instructional Technologies, revealed seven mental images about internet; the internet as a system, as a vehicle, as an addictive entity, as a useful and harmful entity, as an indispensable part of daily life, as an attractive location and as an uncertain entity.

Çoklar\&Bağc1 (2010) explored pre-service teachers' perceptions of the roles of educational technology. They determined six themes for educational technology; being important/useful, assistant/guide, user, producer/designer, learner and attitude. They revealed that metaphor usage differed according to their department. Green \& Stein metz (2010) conducted a similar study to examine the pre-service teachers' beliefs for the roles of educational technology in classroom. However they analy zed the metaphors according to pedagogical orientation of technology. They found that majority of metaphors aligned with behaviorist perspective followed by constructivist and social constructivist.

Gürol\&Donmuş (2010) have examined the pre-service teachers' mental images related to social networks using metaphor. They determined following seven conceptual categories: rapidly developing and changing, communication, correspondence and sharing, addictive, positive, negative, both positive and negative, an indispensableplatform. There was no significant difference among categories of social network related to gender and grade level.

Çoklar, Vural\& Yüksel (2010) investigated metaphors on computer concept developed by undergraduatestudents of Computer Engineering and Computer Education Departments. The findings of the study showed that students used different metaphors according to their departments. While Computer Engineering students developed metaphors representing structural features of computers, Computer Education students developed metaphors representing functions of computers.

Review of literature on the use of metaphors showed that there is scarcity of in depth data examining the perceptions of teachers, ICT coordinators and school administrators. This study is expected to contribute to the educational technology scholarship from the basis of the use of metaphors.

\subsection{The Need and Purpose of the Study}

Although there are a number of metaphoric studies on pre-service teachers, there are limited studies related to perceptions of school administrators, ICT coordinators and teachers about technology concept. Moreover, researches on pre-service teachers suggest to conduct research on technology related metaphoric perception studies on teachers' technology concept (Gök\&Erdoğan, 2010; Green \& Steinmetz, 2010). It is beneficial to figure out the perceptions of in-service teachers and other key stakeholders such as school admin istrators and ICT coordinators in order to fulfill effective ICT integration into schools. Because the negative attitudes and beliefs of the teachers and school administrators about technology can be a major barrier which hinder technology use in teaching and learning process (Hew \& Brush, 2007). In addition ICT coordinators have a crucial role in effective technology integration by collaborating with teachers to encounter problems which teachers face during technology use in teaching process, by developing a technology plan and by maintaining the hardware and by locating the suitable educational software (Balanskat, Blamire\&Kefala, 2006). However, none of the studies identified the perceptions of ICT coordinators using metaphor analysis.

The purpose of the study is to examine the perceptions of school administrators, ICT coordinators and teachers regarding the concept of "technology" using metaphor analysis. Following research questions were addressed in this study;

1) What metaphors do school administrators, ICT coordinators and teachers use regarding technology concept?

2) What conceptual categories can be driven from these metaphors?

3) Do conceptual categories differ regarding position, gender and age?

\section{Method}

\subsection{Participants}

The study was carried out with 87 educators by using maximum variation sampling, which is a type of purposive sampling method. This sampling method aims to form a relatively small sample and have as much variety of individuals whose views can reflect those of the target population (Yıldırım ve Şimşek, 2008, p.107).Therefore, school administrators $(\mathrm{n}=33,37.9 \%)$, teachers from various branches $(n=36,41.4 \%)$ and ICT coordinators $(n=18,20.7 \%)$ who took part in the seminar titled "technology use in schools", were presupposed to have a high degree of awareness regarding the concept of technology.The majority of the participants $(n=56,64.4 \%)$ have been working in elementary schools. 41 male (54.7\%) and 34 female (45.3\%) educators participated in the study. Most of the participants were up to 40 years of age $(n=65,76.4 \%)$ and graduated from university $(n=71,81.4 \%)$. There were 5 educators in total who were between 41-50 and 51 and above age groups. However, in order to be able to compare the age categories these age groups were combined as 41 and above. The demographics of the participants are presented in Table 1.

\subsection{Data Collection}

Metaphor can be used as an important research tool (Saban, 2006). As Jensen (2006) stated “...through metaphors, researcher is able to enter into the inner world of the perceptions, understandings and experiences of the 
participants" (Jensen, 2006). In this study, metaphor was used to collect qualitative data using open ended questions. In metaphor based data collection process the main purpose is to draw a rich portrait of the relating phenomenon by analyzing the open ended question replies of the participants. With the "because....." part in the open ended questions the meaning participants ascribe to the metaphor is tried to be pointed out (Yıld ırım\& Şimşek, 2008, p.212-213).

Table 1. Participants' Demographic Information

\begin{tabular}{ccc|ccc}
\hline & $\mathrm{f}$ & $\%$ & & $\mathrm{f}$ & $\%$ \\
\hline $\begin{array}{c}\text { School level } \\
\text { Elementary }\end{array}$ & 56 & 64.4 & Age & & \\
General & 90 and below & 33 & 38.8 \\
High School & 9 & 10.3 & $31-40$ & 32 & 37.6 \\
$\begin{array}{c}\text { Vocational } \\
\text { High School }\end{array}$ & 22 & 25.3 & 41 and above & 20 & 23.5 \\
$\begin{array}{c}\text { Position } \\
\text { School }\end{array}$ & & & Missing & 2 & \\
administrator & 33 & 37.9 & Education & & \\
$\begin{array}{c}\text { ICT } \\
\text { Coordinator }\end{array}$ & 18 & 20.7 & $\begin{array}{c}\text { Two-year } \\
\text { degree }\end{array}$ & 5 & 5.8 \\
$\begin{array}{c}\text { Teacher } \\
\text { Gender }\end{array}$ & 36 & 41.4 & $\begin{array}{c}\text { Undergraduate } \\
\text { Graduate }\end{array}$ & 71 & 81.4 \\
$\quad$ Male & 41 & 54.7 & 12.8 \\
Female & 34 & 45.3 & & & \\
Missing & 12 & & Total & 87 & 100 \\
\hline
\end{tabular}

Data were collected in 2 separate sessions of the seminar which was about technology usage in schools. At the beginning of the seminar, participants were asked to answer the close-ended questions to reveal the demographic information, and then fill in the statement "Technology is like...because..." focusing on one metaphor. The analogy between the metaphor topic (technology) and the metaphor vehicle (the answer of the participant) was emphasized by using the word "like". The word "because" was used to clarify the implicit beliefs of the participants (Saban et al, 2007). The form also contained demographic information such as gender, age, school level and educational background. After completing the form, focus group discussion was performed to reveal the rationales about the metaphors. The discussions were recorded and transcribed word by word. Pseudonyms were used to ensure the anonymity of the participants. Instead of using a nick name, the statements of the participants were labeled with their position, gender and age.

\subsection{Data Analysis}

Among the forms distributed to the participants the ones $(n=11)$ which were not completed were eliminated. The statements indicated by participants were listed in an excel sheet. During that process, in total 12 forms some of which did not have a metaphor, had more than one metaphors or had a metaphor without the rationale of using the metaphor were left out from analysis After the elimination of 23 forms, the raw data were reorganized to resolve the elements of the metaphor. The subject, source and the rationales of the metaphors were analyzed to develop conceptual themes. 4 poorly structured metaphors were eliminated at this stage because of their difficulty of placing them in one conceptual theme or lack of logical rationale. It was found that 87 participants indicated 60 valid metaphors. Then the metaphors were reorganized in alphabetical order for categorization. As Moser (2000) stated content analysis is fruitful for understanding the metaphorical expressions, the metaphors and the rationales were reviewed many times to determine which conceptual category would be best to represent the participants' perceptions about technology. Through the content analysis, five categories were determined.

In order to assure validity in qualitative research it is important to make in detail descriptions for each step, to use a rich sample employing purposive sampling, to give the characteristics of the participants and to make direct quotations from the statements of the participants (Yildirım ve Şimşek, 2008, p.257-259). In this study a purposive sample which can reflect varied views of the participants regarding technology was chosen; the characteristics of the participants were explained, and each research step was explained in detail. In addition to this, the metaphors participants produced and their rational regarding the metaphors were given in direct quotations.

In order to assure the reliability of qualitative research it is important that the researcher gives detailed information about his position and place during the research process, and testifies the results with data (Yıld ırım ve Şimşek, 2008, p.262-263). Researcher delivered the forms at the beginning of the seminar program, did not interfere during the metaphor writing process and did not convey any thoughts or make any interventions during the focus group study. To determine the inter-rate reliability, consistency analysis was employed. To assure consistency analysis the list of the metaphors and categories were given to 2 experts in qualitative data analysis. The matching experts did between the metaphors and their categories was calculated using the formula (Reliability=agreement/ [agreement+disagreement] $X$ 100) suggested by Miles \&Huberman (1994). Miles \&Huberman (1994, p.64) suggest that final inter-coder agreement score in qualitative data analysis should approach or exceed 0.90. In the study the researcher's degree of compromise was 0.97 with the first expert and 0.98 with the second expert.

The quantitative analysis techniques are powerful tools to reveal the general tendencies of metaphor use (Moser, 2000). The demographic data and the qualitative data were transferred and coded into SPSS program to calculate the frequencies and percentages of the used metaphors and their categories. In addition chi-square was used to compare metaphor categories like position, gender and age.

\section{Findings}

The participants generated 60 valid metaphors. Metaphors 
emphasized by most of the participants are as follows: water $(\mathrm{f}=5,5.7 \%)$, child ( $\mathrm{f}=5,5.7 \%)$, sun $(\mathrm{f}=4,4.6 \%)$, light $(\mathrm{f}=4$, $4.6 \%)$, sea $(\mathrm{f}=3,3.4 \%)$, car $(\mathrm{f}=3,3.4 \%)$, fashion $(\mathrm{f}=2,2.3 \%)$, salt $(\mathrm{f}=2,2.3 \%)$, river $(\mathrm{f}=2,2.3 \%)$, baby $(\mathrm{f}=2,2.3 \%)$, snowball $(\mathrm{f}=2,2.3 \%)$ and life $(\mathrm{f}=2,2.3 \%)$.

Participants' perceptions oftechnology were determined under 5 main categories, which were entitled as technology as a useful and harmful entity (28.7\%), technology as a changing and developing entity (25.3\%), technology as facilitator $(24.1 \%)$, technology as a needed entity $(13 \%)$ andtechnology as a diffusional entity (6.9\%).

\subsection{Categories according to School Administrators, ICT Coor dinators and Te achers}

Table 2 reveals the frequency and percentage distribution of categories with regards to position variable. As could be seen in the Table 2 below, most of the school administrators perceived technology as both a useful and harmful entity (30.3\%) whileICT coordinators perceive it as a facilitator (44.4\%) and teachers as achanging and developing entity (36.1\%).

Pearson chi-square analysis was used to test whether these results differ significantly with regards to position variable. Results of the analysis showed that perceptions of school administrators differ significantly among ICT coordinators and teachers $\left[x^{2}=17.733, p<.05\right]$.

Technology as needed and diffusional entity was the least mentioned category by the school administrators among other categories. As well none of the ICT coordinators perceived technology as a "changing and developing entity". None of the teachers mentioned technology as a "diffusional entity".

Table 2. The distribution of categories according to position

\begin{tabular}{|c|c|c|c|c|c|c|c|c|}
\hline Categories & Adn & $\begin{array}{l}\text { sol } \\
\text { strator }\end{array}$ & $\mathrm{Coc}$ & $\begin{array}{l}T \\
\text { inator }\end{array}$ & & cher & & tal \\
\hline $\begin{array}{c}\text { Technology } \\
\text { as a... }\end{array}$ & $\mathrm{f}$ & $\%$ & $\mathrm{f}$ & $\%$ & $\mathrm{f}$ & $\%$ & $\mathrm{f}$ & $\%$ \\
\hline $\begin{array}{l}\text { useful and } \\
\text { harmful } \\
\text { entity }\end{array}$ & 10 & 30.3 & 4 & 22.2 & 11 & 30.6 & 25 & 28.7 \\
\hline $\begin{array}{l}\text { and } \\
\text { developing } \\
\text { entity }\end{array}$ & 9 & 27.3 & 0 & - & 13 & 36.1 & 22 & 25.3 \\
\hline Facilitator & 8 & 24.2 & 8 & 44.4 & 5 & 13.9 & 21 & 24.1 \\
\hline $\begin{array}{c}\text { needed } \\
\text { entity }\end{array}$ & 3 & 9.1 & 3 & 16.7 & 7 & 19.4 & 13 & 14.9 \\
\hline $\begin{array}{l}\text { diffusional } \\
\text { entity }\end{array}$ & 3 & 9.1 & 3 & 16.7 & 0 & - & 6 & 6.9 \\
\hline Total & 33 & 100 & 18 & 100 & 36 & 100 & 87 & 100 \\
\hline
\end{tabular}

\subsection{Main Conceptual Categ ories of Technol ogy}

\subsubsection{Technology as a useful and harmful entity}

25 participants developed 20 metaphors under this conceptual category. The following four metaphors were dominant: salt (12.0\%), child (8.0\%), sea (8.0\%) and sugar $(8.0 \%)$.

25 participants highlighted both positive and negative attributes of technology. Under this category, it is apparent that participants perceive technology as both a useful and a harmful entity. One male school administrator used the metaphor of salt to describe this shift between being useful and harmful. His words echoed many of the participants:

Technology is like a salt, it gives harm when it is used too much (School Administrator, Male, Age 31-40).

Table 3. Technology as a useful and harmful entity

\begin{tabular}{cccccc}
\hline $\begin{array}{c}\text { Metaphor } \\
\text { name }\end{array}$ & $\mathrm{f}$ & $\%$ & $\begin{array}{c}\text { Metaphor } \\
\text { name }\end{array}$ & $\mathrm{f}$ & $\%$ \\
\hline Salt & 3 & 12,0 & Value & 1 & 4,0 \\
Child & 2 & 8,0 & Detergent & 1 & 4,0 \\
Sea & 2 & 8,0 & Disco & 1 & 4,0 \\
Sugar & 2 & 8,0 & Eddy & 1 & 4,0 \\
Injection & 1 & 4,0 & Sun & 1 & 4,0 \\
Shoe & 1 & 4,0 & Dough & 1 & 4,0 \\
Separator & 1 & 4,0 & Projector & 1 & 4,0 \\
Knife & 1 & 4,0 & Water & 1 & 4,0 \\
Flower & 1 & 4,0 & Wine & 1 & 4,0 \\
Chocolate & 1 & 4,0 & Virus & 1 & 4,0 \\
& & & Total & 25 & 100 \\
\hline
\end{tabular}

A similar rational was also seen in the metaphor of sugar with the following words:

Technology is like a sugar, it gives a sweet aroma to our mouth. However using too much sugar may be harmful for our health (School Administrator, Age 41 and above).

Technology is like using a sugar. If you take too much sugar you might be sick (ICT Coordinator, Female, age under 30$)$.

Under the category of technology as a useful and harmful entity, participants also mentioned potential risks that could be encountered during the implementation phase. 2 participants used the metaphor of child to show the way how special care and attention should be given when using technology with the following words:

Technology is like a child. She or he may embarrass you at an unexpected time and place (Teacher, Female, Age 31-40).

The other participants revealed the metaphor of child from another perspective by saying that "Technology is like a child, when necessary information, support and care is given then the child presents the expected outcome" (Teacher, Female, Age under 31)".

Under this category, some of the participants used the metaphor of sea to illustrate the extent to which technology broadens new horizons at schools. This was expressed with the following words:

Technology is like the sea. When you dive into water you can find many different things. If you do not know how to swim you might be drowned (Teacher, Female, Age 31-40)

Another school administrator asserted that"Technology is like water. The more you use the more you feel better (School Administrator, Age 31-40)". In line with this metaphor, another school administrator (Male, Age 41 and above) used wine to indicate that technology makes him extremely happy since he feels dizzy after using it.

3.2.2. Technology as a changing and developing entity 
22 participants developed 18 metaphors under this conceptual category. The following three metaphors were dominant: child (13.6\%), fashion (9.1\%) and river (9.1\%).

One third of the participants used metaphors, which fall into the category of technology as a changing and developing entity. They used metaphors mostly related with nature to reflect the changing and developing nature of the technology. Excerpt below reveals the connection between nature and technology:

Technology is like a river, because it continuously flows and changes (Teacher, Female, age under 31).

Another nature metaphor was found in the use of sun by one of the respondents with the following words: "Technology is like a sun, it raises, gives light and sets. A new day is born with the rising sun (Administrator, Male, age 41 and above)."

Table 4. Technology as a changing and developing entity

\begin{tabular}{cccccc}
\hline $\begin{array}{c}\text { Metaphor } \\
\text { name }\end{array}$ & $\mathrm{f}$ & $\%$ & $\begin{array}{c}\text { Metaphor } \\
\text { name }\end{array}$ & $\mathrm{f}$ & $\%$ \\
\hline Child & 3 & 13,6 & Sun & 1 & 4,5 \\
Fashion & 2 & 9,1 & Weather & 1 & 4,5 \\
condition & 1 & \\
River & 2 & 9,1 & Light & 1 & 4,5 \\
Baby & 1 & 4,5 & Woman & 1 & 4,5 \\
Chameleon & 1 & 4,5 & Snowball & 1 & 4,5 \\
Living being & 1 & 4,5 & Watch & 1 & 4,5 \\
Underwear & 1 & 4,5 & Etemity & 1 & 4,5 \\
Avalanche & 1 & 4,5 & Water & 1 & 4,5 \\
Factory & 1 & 4,5 & Life & 1 & 4,5 \\
& & & Total & 22 & 100 \\
\hline
\end{tabular}

In line with the idea of developing and changing entity, the metaphor of child is used with the following phrase: "Technology is like a child, because it grows up and develops (School administrator, male, age under31)". The metaphor of child not only reveals the growing process but also the joy, life and happiness embedded within the process. This was also expressed by some of the participants during the focus group discussions. Participants indicated that introduction of technology brought a new life to most of the schools, where teachers, administrators and students felt the joy and excitement of a new adventure. They also indicated that technology provided them with lots of opportunities in the learning and teaching processes in a way that courses became more interesting and effective. However a few respondents also indicatedthatthe balance should be maintained in order to prevent any sort of biases that could come out during the implementation phase. As could be seen in the two categories above, the metaphor of child is used under the two different categories. This might be an indicator that technology opens new learning paths for the teachers. However, it should be approached and handled with great care. Almost all of the participants in the focus groups revealed similar feeling mixed with "excitement and concern".

Fashion and chameleon, are the other metaphors used to express the changing nature of technology.

Technology is like fashion because it constantly changes
(Administrator, age 31-40)

Technology is like a chameleon because it constantly changes and develops (Teacher, Male, age 31-40)

\subsubsection{Technology as a facilitator}

Facilitator is the third category determined in the study. This category is entitled as facilitator to cover the metaphors indicating that technology enables individuals and groups to work effectively and efficiently.

A quarter of the participants attributed metaphors related to being a facilitator. Participants, who used metaphors under this category, used the ones that signify the benefit of technology at school. Sun, light and car are the metaphors used to reveal the benefits of technology. Excerpts given below project the views of the participants with regards to light and car metaphors:

Technology is like light, which lightens our way (Teacher, age 31-40).

Technology is like a sun because it enlightens the surrounding (Teacher, Female, age under 31).

Technology is like a car because it helps individuals to reach the information and use it (ICT Coord inator, Male, age under 31).

Technology is like a catalyst, because it makes the lives easier and fast (Teacher, Male, age 31-40).

Table 5. Technology as a facilitator

\begin{tabular}{cccccc}
\hline Metaphor name & $\mathrm{f}$ & $\%$ & Metaphor name & $\mathrm{f}$ & $\%$ \\
\hline Car & 3 & 14,3 & Sun & 1 & 4,8 \\
Light & 3 & 14,3 & Airline & 1 & 4,8 \\
Bulb & 1 & 4,8 & Servant & 1 & 4,8 \\
Key & 1 & 4,8 & Catalyst & 1 & 4,8 \\
Mother & 1 & 4,8 & Bridge & 1 & 4,8 \\
Antibiotics & 1 & 4,8 & Organ & 1 & 4,8 \\
EMS (Express Mail & 1 & 4,8 & Teacher & 1 & 4,8 \\
Service) & 1 & 4,8 & Road & 1 & 4,8 \\
Biopsy & 1 & 4,8 & Total & 21 & 100 \\
Google & & & & &
\end{tabular}

From another perspective one of the participants used the metaphor of Google search engine for technology, when talking about the benefits and use of technology in the lives of teachers and students. Her words reveal the way in which technology is incorporated into the lives of the teachers:

Technology is like Google search engine, you can find whatever you search for (ICT Coordinator, Female, age under 31).

One of the participants used the metaphor of antibiotics to describe the healing power of technology in educational settings. The use of metaphor indicates that it solves the problems encountered on a long term basis. ICT Coordinator's words echoed most of the respondents in the focus group discussions:

Technology is like antibiotics because problems could be solved in some ways but technology provides fast and long lasting solutions (ICT Coordinator, Male, age 31-40).

It was revealed in the focus group discussions that use of antibiotics as a metaphor might symbolize the face of two 
mirrors. From the direct perspective, it provides treatment for a learning setting. However, participants also mentioned the risks of antibiotics by saying that, it could be harmful if it is not used consciously. As in the case of using medicine, teachers should be aware that technology is a means not an end. In line with this argument, some of the participants mentioned that technology serves as a bridge that connects teachers, students and administrators. The teacher's reflections below reflect some of the respondents' perspectives on the use of technology.

Technology is like a bridge because it connects people (Teacher, Female, age under 31).

In the focus group discussions, reflections on the metaphor of bridge seem to be in parallel with the ideas put forward as in the case of antibiotics. Half of the participants asserted that they embrace technology and they try to connect with their students in the cyber world as well. They said it is inevitable to eliminate ourselves from our students in the cyber world. From another perspective, the other half resisted sharing their privacy with their students in the cyber world. They said they do not want to connect with their students in Facebook or Twitter. These two metaphors however brought the dilemma experienced when using technology in our classes as well as incorporating it in our academic and daily lives. Almost all the participants in the focus groups agreed that keeping the balance in the use of technology might be the secret word to achieve productive and long lasting solutions.

\subsubsection{Technology as a needed entity}

Thirteen percent of the participants used 13 metaphors, which fall into the category of technology as a needed entity. Water $(23.1 \%)$ was the dominant metaphor which was used by the participants.

Table 6. T echnology as a needed entity

\begin{tabular}{cccccc}
\hline $\begin{array}{c}\text { Metaphor } \\
\text { name }\end{array}$ & $\mathrm{f}$ & $\%$ & $\begin{array}{c}\text { Metaphor } \\
\text { name }\end{array}$ & $\mathrm{f}$ & $\%$ \\
\hline Water & 3 & $\begin{array}{c}23, \\
1\end{array}$ & Air & 1 & 7,7 \\
Brain & 1 & 7,7 & Leader & 1 & 7,7 \\
Bread-water & 1 & 7,7 & Oxygen & 1 & 7,7 \\
Food & 1 & 7,7 & Life & 1 & 7,7 \\
Glasses & 1 & 7,7 & Gravity & 1 & 7,7 \\
Sun & 1 & 7,7 & Total & 13 & 100 \\
\hline
\end{tabular}

Technology was associated with food related concepts like water, bread and food in that category. 5 part icipants used the names of fundamental food to indicate the value of technology in teachers' lives. This was mentioned by both administrators and the teachers:

Technology is like food, it is the main source of development (Administrator, Male, age 41 and above)

Technology is like water, because we cannot live without water (ICT Coordinator, Male, age under 31).

Technology is like water because you need water even though you do not want to drink. You need to benefit from technology and you need to include technology in our lives
(Teacher, Female, age under 31).

These expressions were echoed in the focus discussions as well. Participants indicated that technology became a fundamental ingredient in schools. They said in this new era technology is needed to survive like bread and water. In line with this idea the use of sun also reveals this fundamental need.

Technology is like sun. If there is no sun light we are left in darkness (Teacher, Female, age under 31)

\subsubsection{Technology as a diffusional entity}

One of the categories that align with technology metaphor is technology as a diffusional entity. 6.9 percent of the participants used 6 metaphors under that category.

Table 7.Technology as diffusionalent ity

\begin{tabular}{ccc}
\hline Met aphor name & f & \% \\
\hline Octopus & 1 & 16,7 \\
Sea & 1 & 16,7 \\
World & 1 & 16,7 \\
Snowball & 1 & 16,7 \\
Ocean & 1 & 16,7 \\
Chat & 1 & 16,7 \\
Total & 6 & 100 \\
\hline
\end{tabular}

It was observed during the analysis that participants used pastoral metaphors to indicate that technology has a power to embrace educational settings, including students and administrators alike. This has been revealed in the metaphors of octopus, sea, world, snowball and ocean with the following statements:

Technology is like octopus because it encompassed our lives from every dimension (School Administrator, Male, age 41 and above),

Technology is like world because it involves everyone and it acknowledges everyone no matter which part of the world an individual lives (ICT Coordinator, Female, age under 31).

Use of pastoral images appeared to be significant in the focus group discussions as well. Participants had the tendency to use commonly accepted metaphors to emphasize the scope and the strength of technology in education. Almost all of the participants pointed out the positive aspects of technology in teaching and learning processes at schools and they used the metaphors of sea and snowball to signify the impact of technology. One of the administrators used the metaphor of snowball as follows:

Technology has a chain reaction effect on the educational processes. Like a snowball once you start this process, it gets bigger and more powerful in each move (Focus Group Reflections, Administrator, age 41 and above).

Excerpt given below was echoed in most of the respondents' words during the focus group discussions. The chain reaction effect was underlined as one of the main qualities of technology.

\subsection{Effects of Gender and Age}

Since 10 participants did not mention their ages, calculations were done out of 75 participants. The results of 
the chi-square analysis concerning categories according to participants' gender (Table 8) and age (Table 9) are presented below.

It was revealed in the analysis that most of the male respondents perceive technology as a changing and developing entity while most of the female respondents perceive it as a useful and harmful entity. Participants' perceptions do not differ significantly with regards to gender variable $\left[x^{2}=2.828, p>05\right]$. Although no statistical significance was observed with regards to gender, frequency and percent distribution of participants in the different categories may highlight important gender related tendencies. During the focus group discussions, female participants were observed to be putting more emphasis on the dual nature of technology when compared to their male counterparts. Female part icipants not only stressed the value of technology in educational settings but also warned the potential dangers that might emerge as a result of misuse or overuse of technology. A few male respondents also revealed similar concerns as well.

Table 8.Categories according to gender

\begin{tabular}{|c|c|c|c|c|c|c|}
\hline \multirow{2}{*}{ Categories } & \multicolumn{4}{|c|}{ Gender } & \multirow{2}{*}{\multicolumn{2}{|c|}{ Total }} \\
\hline & \multicolumn{2}{|c|}{ Men } & \multicolumn{2}{|c|}{ Woman } & & \\
\hline Technology as a.. & $\mathrm{f}$ & $\%$ & $\mathrm{f}$ & $\%$ & $\mathrm{f}$ & $\%$ \\
\hline useful and harmful entity & 9 & 22.0 & 12 & 35.3 & 21 & 28.0 \\
\hline changing and developing entity & 12 & 29.3 & 8 & 23.5 & 20 & 26.7 \\
\hline facilitator & 11 & 26.8 & 6 & 17.6 & 17 & 22.7 \\
\hline needed entity & 5 & 12.2 & 6 & 17.6 & 11 & 14.7 \\
\hline diffusional entity & 4 & 9.8 & 2 & 5.9 & 6 & 8.0 \\
\hline Total & 41 & 100 & 34 & 100 & 75 & 100 \\
\hline \multicolumn{7}{|c|}{$\mathrm{x} 2=2.828, \mathrm{df}=4, \mathrm{p}=.587$} \\
\hline
\end{tabular}

Table 9.Categories according to age

\begin{tabular}{|c|c|c|c|c|c|c|c|c|}
\hline \multirow{3}{*}{$\begin{array}{c}\text { Cat egories } \\
\text { Technology } \\
\text { as a... }\end{array}$} & \multicolumn{6}{|c|}{ Age } & \multirow{2}{*}{\multicolumn{2}{|c|}{ Total }} \\
\hline & \multicolumn{2}{|c|}{$\begin{array}{l}30 \text { and } \\
\text { below }\end{array}$} & \multicolumn{2}{|c|}{$31-40$} & \multicolumn{2}{|c|}{$\begin{array}{l}41 \text { and } \\
\text { above }\end{array}$} & & \\
\hline & $\mathrm{f}$ & $\%$ & $\mathrm{f}$ & $\%$ & $\mathrm{f}$ & $\%$ & $\mathrm{f}$ & $\%$ \\
\hline $\begin{array}{l}\text { useful and } \\
\text { harmful } \\
\text { entity }\end{array}$ & 9 & 27.3 & 10 & 31.3 & 5 & 25.0 & 24 & 28.2 \\
\hline $\begin{array}{l}\text { changing } \\
\text { and } \\
\text { developing } \\
\text { entity }\end{array}$ & 4 & 12.1 & 14 & 43.8 & 4 & 20.0 & 22 & 25.9 \\
\hline facilitator & 12 & 36.4 & 4 & 12.5 & 4 & 20.0 & 20 & 23.5 \\
\hline $\begin{array}{c}\text { needed } \\
\text { entity }\end{array}$ & 6 & 18.2 & 2 & 6.3 & 5 & 25.0 & 13 & 15.3 \\
\hline $\begin{array}{l}\text { diffusional } \\
\text { entity }\end{array}$ & 2 & 6.1 & 2 & 6.3 & 2 & 10.0 & 6 & 7.1 \\
\hline Total & 33 & 100 & 32 & 100 & 20 & 100 & 85 & 100 \\
\hline
\end{tabular}

36 percent of the participants under the age of 30 perceived technology as a facilitator while 43 percent of the participants within the range of 31-40 age group perceived it as a changing and developing entity. Perceptions of the participants who fall into the 41 and above range age group appeared to be distributed on a wider category. 25 percent perceived it as a useful and harmful entity, 20 percent as a changing and developing entity, 20 percent as a facilitator, 25 percent as a needed entity and 10 percent perceived it as a diffusional entity. No significance was found with regards to the age variable $\left[x^{2}=14.332, p>.05\right]$.

\section{Discussion}

The school administrators', teachers' and ICT coordinators' attitudes towards technology use in education is an important component of the technology integration process (Hew \& Brush, 2007; Lai et al, 2001; Mazman\&KoçakUsluel, 2011). In this study; based on the metaphor analysis, five main categories emerged: "technology as a useful and harmful entity", "technology as a changing and developing entity", "technology as a facilitator", "technology as a needed entity" and "technology as a diffusional entity". In parallel with these findings, Gök\&Erdoğan (2010) proposed similar categories in their study on primary pre-service teachers' perceptions about technology.

Most of the participants mentioned both positive and negative attributes of the technology. They highlight the shift between being useful to being harmful under the category "useful and harmful entity". Participants' reflections revealed that technology is useful but it has potential risks when inappropriate use. They highlighted the potentials dangers that might emerge as a result of misuse or overuse of technology. In this context, they stressed the concept of balance to indicate the thin line between being useful and harmful. Following words taken by a male participant from focus group discussions echoes most of the participants' views on this issue:

Technology is one of the basic ingredients of our teaching and learning lives. We should be aware of the fact that too little or too much of it could give harm rather than the benefit.

This excerpt also indicates that technology is a tool, which makes our lives better and it should not be perceived as our goal. However, several participants criticised some administrators' result oriented attempts in order to leave a good impression in front of the stakeholders, such as local ministries of education, parents and alike. Most of the teachers and ICT coordinators warned about the potential risks that could be encountered in such school settings. They all indicated that school administrators have important roles in this process and they all underlined the importance of establishing a collaborative learning culture fed with technology. Similarly, Lam (2000) found that the teachers saw technology as a tool, as a means toenhance teaching and promote learning, not as an end in itself.

School administrators and teachers asserted the changing and developing nature of the technology, which brings a new adventure to schools. They emphasized the excitement and concern about the changing side of technology. While most of the teachers perceived technology as a changing and developing entity, none of the ICT Coord inators indicated a 
metaphor in that category. The reason could be the nature of the job of being an ICT Coordinator which is required to accept the changing nature of ICT. For this reason, ICT Coordinators might have not given any metaphors in that category. However most of the ICT Coordinators perceive technology as a facilitator which makes the job easier. Other research results showed that they have various roles in technology integration such as technical supporter, pedagogical supporter and planner and they have positive attitudes towards technology (Akkoyunlu, 1995; Devolder, 2009; Lai \& Pratt, 2004). Therefore by using technology as a facilitator, ICT Coordinators can overcome such expected duties.

Educators indicated that technology became a fundamental ingredient in schools. They emphasized that technology is needed to survivein this new dig ital age. They gave food related concepts to explain how much they needed to use technology in schools. However the findings of the focus group discussion stressed keeping the balance in the use of technology in or out of the school. It was revealed in the metaphors that some metaphors could overlap in more than one category. This is especially evident in the use of metaphors which pinpoint the importance of balance when using it. Most of the participants indicated that effective use of technology could be maintained through the active participation of all school adminis trators, teachers, students, admin staff and alike. They asserted that this fundamental ingredient should be shared within the whole school culture. As previous research suggested, shared technology leadership and commitment of the school team are facilitators of successful technology integration (Hsu \& Sharma, 2008; Kocolowski, 2010; So mekh et al 2002; Sugar \&Hollomon, 2009). One of the subtle findings of this research highlights the value attached to team culture a mong the participants. One of the participants revealed this idea with the following phrase in focus group discussion:

This is our culture.... We love to share our food ... Like the food, we are supposed to share the technology learning culture ... In this way, thetechnology (food) would give life and energy to the whole school.

School ad min istrators and ICT coordinators used pastoral metaphors to reflect the snowball effect of the technology under diffusional entity category. As well as emphasizing the scope and the strength of technology, they also indicated the continuous expansion of technology in education. Nevertheless, none of the teachers perceive technology as a diffusional entity. In fact, most of the teachers emphasized the changing and developing nature of the technology instead of diffusion of technology.

Educators' perceptions of technology didn't differ regarding gender and age parallel to the results of previous metaphor studies (Cerit, 2008; Gök\&Erdoğan, 2010; Gürol\&Don muş, 2010) despite some tendencies were noted. While most of the male educators perceive technology as a changing and developing entity, most of the female educators perceive it as a useful and harmful entity. Most of the participants under the age of 30 perceived technology as a facilitator while the participants within the range of 31-40 age group perceived it as a changing and developing entity.

\section{Conclusions}

This study revealed the metaphorical conceptualizations of technology perceived by school administrators, teachers and ICT coordinators. In the context of technology use, educators play significant roles in technology integration in schools. However they understand the nature of technology in different ways, they all have positive perceptions about technology. In addition, they have dilemmas about how to balance the technology use, and how and when to use technology. These questions have been asked by many educators, however there isn't any one formula that fits in every educational settings. In one respect, the perceptions of the educators prospect that innovative solutions could be realized by educators' collaborative effort for effective technology integration in schools.

\section{ACKNOWLEDGEMENTS}

The author would like to thank Özge Hacıfazlığlu and Gülay Dalgıç for their valuable comments and support throughout the research.

\section{REFERENCES}

[1] Afacan, Ö. (2011). Fen bilgisi öğretmen adaylarının “fen” ve “fen ve teknoloji öğretmeni” kavramlarına yönelik metaphor durumları. Education Sciences, 6(1), 1242-1254

[2] Akkoyunlu, B. (1995). Bilgi teknolojilerinin okullarda kullanımı ve öğretmenlerin rolü. Hacettepe Universitesi Eğitim Fakültesi Dergisi, 11, 105-109

[3] Albirini, A. (2006). Teachers' attitudes toward information and communication technologies: the case of Syrian EFL teachers. Computers \& Education, 47(4), 373-398

[4] Balanskat, A., Blamire, R.\&Kefala, S. (2006). The ICT impact report: A review of studies of ICT impact on schools in Europe. European Schoolnet. Retrieved January 2011from http://ec.europa.eu/education/pdf/ doc254_en.pdf

[5] Bullough, Jr. R. Y. (1991). Exploring personal teaching metaphors in preservice teacher education. Journal of Teacher Education, 42( 1 ),43-51

[6] Bullough, Jr. R. Y. \& Stokes, D.K. (1994). Analyzing personal teaching metaphors in preservice teacher education as a means for encouraging professional development. American Educational Research Journal, 31(1), 197-224

[7] Cerit, Y. (2008). Ö ğrenci, öğretmen ve yöneticilerinmüdürkavramıileilgilimetaforlarailişkin görüşleri. Education \& Sciences, 33(147), 3-13

[8] Cleere, A.J. (2009). An examination of the role of the ICT coordinator in the secondary school system in Ireland. Unpublished master thesis. University of Limerick 
[9] Çakır, R. \&Yıldırım, S. (2009). What do computer teachers think about the factors affecting technology integration in schools? İlkögretim Online, 8(3), 952-964

[10] Çoklar, A.N. \&Bağc1, H. (2010). What are the roles of prospective teachers on the educational technology use: A metaphor study. World Journal on Educational Technology, 2(3), 186-195

[11] Çoklar, A.N., Vural, L. \& Yüksel, İ. (2010) Bilgisay armühendis liğiilebilgisay ar ve ögretimteknolojilerie ğitimi son sınıföğrencilerininbilgisayar kavramına ilişkin geliştirdikleri mecazlar. Kuramsal Ĕgitimbilim, 3(1), 1-28

[12] Devolder, A. (2009).De ICT-coördinator in Vlaanderen :roldefiniëringen en visie op de ICT-eindtermen. Unpublished Master Thesis, Ghent University

[13] EraslanÇapan, B. (2010). Öğretmenaday larınınüstünyetenekl iö ğrencilereilişkinmetafor ikalgıları. UluslararasıSosyalAraşt trmalarDergisi, 3(12), 140-154

[14] Green, M. \& Steinmetz, L. (2010).What are they thinking? Using metaphor analysis to gain insight into preservice teacher technology beliefs. The Annual Conference of the International Society for Technology in Education (ISTE) 2010, Retrieved January 2011 from http://center.uoregon. edu /conferences/ISTE/2010/

handout_uploads/KEY_49953327/Green_Technology Metap horISTE_RP.pdf

[15] Gök, B. \&Erdoğan, T. (2010). Investigation of pre-service teachers' perceptions about concept of technology through metaphor analysis.TOJET: The Turkish Online Journal of Educational Technology, 9(2), 145-160

[16] Guerrero, M.C.M. \&Villamil, O.S. (2000). ESL teachers roles through metaphor analysis. TESOL Quarterly, 34(2), 341-351

[17] Gulbahar, Y. (2007). Technology planning: A roadmap to successful technology integration in schools. Computers \& Education, 49, 943-956

[18] Gürol, M. \&Donmuș, V. (2010). Metaphors created by prospective teachers related to the concept of "Social Network".Procedia Social and Behavioral Sciences, 9, 1489-1496

[19] Hew, K.F. \& Brush, T. (2007). Integrating technology into $\mathrm{K}-12$ teaching and learning: Current knowledge gaps and recommendations for future research. Educational Technology Research \& Development, 55,223-252

[20] Hsu, P-S., \& Sharma, P. (2008). A case study of enabling factors in the technology integration change process. Educational Technology \& Society, 11 (4), 213-228

[21] Jensen, D. F. N. (2006). Metaphors as a bridge to understanding educational and social contexts. International Journal of Qualitative Methods, 5(1), Article 4. Retrieved 12 December 2010 from http://www.ualberta.ca/ iiqm/backissues/5_1/pdf/jensen.pdf

[22] Kocolowski, M.D. (2010). Shared leadership: Is it time for a change? Emerging Leadership Journeys, 3(1), 22-32

[23] Lai K.W., Pratt K. \&Trewern, A. (2001) Learning with technology: evaluation of the Otago secondary schools technology project. The Community Trust of Otago, Dunedin

[24] Lai K.W. \& Pratt K. (2004). Information and communication technology (ICT) in secondary schools: the role of the computer coordinator. British Journal of Educational Technology, 35(4), 461-475

[25] Lam, Y. (2000). Technophilia vs. technophobia: A preliminary look at why second-language teachers do or do not use technology in their classrooms. The Canadian Modern Language Review, 56(3), 389-420

[26] Lucock, S \& Underwood, G. (2001). The role of the ICT coordinator. Retrieved 15 December 2010 from http://www.pfp-publishing.com/primary/ict-cont.htm

[27] Lakoff, G. \& Johnson, M. (1980): Metaphors we live by. Chicago: University of Chicago Press

[28] Mazman, S. G. \&KoçakUsluel, Y. (2011). Bilgi ve iletişimteknolojilerininö grenme-öğretmesüreçlerineentegrasy onu: Modeller ve göstergeler. Eğitim Teknolojisi Kuram ve Uygulama, 1(1), 62-79

[29] Miles, M. B. \&Huberman, A. M. (1994). Qualitative data analy sis (2nd ed.). Thousand Oaks, CA: Sage Pub

[30] Moser, Karin S. (2000). Metaphor analysis in psy chology-M ethod, theory, and fields of application. Forum: Qualitative Social Research, 1(2), Retrieved 10 October 2010 from http://nbn-resolving.de/urn:nbn:de:0114-fqs0002212

[31] Nikitina L. \&Furuoka, F. (2008). Measuring Metaphors: A Factor Analysis of Students' Conceptions of Language Teachers. Metaphor.de, 15, 161-180

[32] Ocak, G. \&Gündüz, M. (2006). Eğitim fakültesiniy enikazananö ğretmenad ay larınınögretmen likmesl eğine girişdersinialmadanönce ve aldıktansonraö ğretmenlikm esleğihakk ındakimetaforlarınınkarşılaştırılması.

SosyalBilimlerDergisi, 8(2), 293-310

[33] Orhan, F. \&Akkoyunlu, B. (2003). Eğiticibilgisay arformatör (master) ögretmen lerininprofilleri ve uy gulamadakarşılaştıkl arıüçlük lereilişkingörüşleri. HacettepeÜniversitesi Eğitim FakültesiDergisi, 24, 90-100

[34] Oxford, R., Tomlinson, S., Barcelos, A., Harrington, C., Lavine, R.Z., Saleh, A. \&Longhini, A. (1998). Clashing metaphors about classroom teachers: Toward a systematic typology for the language teaching field. System 26(1), 3-50

[35] Reilly, R. (1999) The technology coordinator: curriculum leader or electronic janitor? MultiMedia Schools, May/June, 38-41. Retrieved 10 December 2010 from http://www.umass.edu/ednet/janitor.html

[36] Saban, A. (2006). Functions of metaphor in teaching and teacher education: A review essay. Teaching Education, 17(4), $299-315$

[37] Saban, A. (2007). Seçmeciokulteknolojiplanlamamodeli ve Özel Konya Esentepel̇lköğretimOkuluteknolojiprofili. SosyalBilimlerEnstitüsüDergisi, 22(1), 23-43

[38] Saban, A., Kocbeker B.N. \&Saban, A. (2007). Prospective teachers' conceptions of teaching and learning revealed through metaphor analysis. Learning and Instruction, 17, 123-139

[39] Saban, A. (2009). Öğretmenaday larınınöğren cikavramınailiş kinsahip olduklarızihinselimgeler. Türk Eğitim BilimleriDerg isi, 7(2), 281-326

[40] Saban, A. (2010).Computer teacher candidates' metaphors 
about the internet. Education, 131(1), 93-105

[41] Sackman, S. (1989). The role of metaphors in organizational transformation. Human Relations, 42(6), 463-485

[42] Silman, F. ve Şimşek, H. (2006). Türkiye ve Amerikabirleşikdevletleriokulları ve merkezieğitimkurumlar ınamecazlaryoluy labirbakış. Ĕgitim AraştırmalarıDergisi. 23, $177-187$

[43] Somekh B., Woodrow, D. Barnes S., Triggs P., Sutherland R., Passey D., Holt H., Harrison C., Fisher T., Flett A. \&Joyes, G. (2002) NGfL pathfinders: Final report on the roll-out of the NGfLprogramme in ten pathfinder LEAs. Retrieved 12 April 2011from.http://www.becta.org.uk/page_documents/researc h/ngflseries_pathfinders.pdf.

[44] Sugar, W. \& Holloman, H. (2009). Technology leaders wanted: Acknowledging the leadership role of a technology coordinator. TechTrends, 53(6), 66-74

[45] Thomas, L. \& Beauchamp, C. (2011). Understanding new teachers' professional identities through metaphor. Teaching and Teacher Education, 27, 762-769

[46] Tondeur, J., Keer H., Braak, J. \&Valcke, M. (2008). ICT integration in the classroom: Challenging the potential of a school policy. Computers \& Education, 51, 212-223

[47] Yıldırım, A. \&Şimşek, H. (2008). Sosyal bilimlerde nitel araştırma yöntemleri (7. Baskı). Ankara: Seçkin Yayıncılık 